\title{
Top 7 Lessons Learned from COVID-19 Pandemic
}

This paper was downloaded from TechRxiv (https://www.techrxiv.org).

\section{LICENSE}

CC BY 4.0

SUBMISSION DATE / POSTED DATE

07-05-2020 / 08-05-2020

\section{CITATION}

Jayakumar, Priyanka; Brohi, Sarfraz Nawaz; Zaman, Noor (2020): Top 7 Lessons Learned from COVID-19 Pandemic. TechRxiv. Preprint. https://doi.org/10.36227/techrxiv.12264722.v1

$\mathrm{DOI}$ 


\section{Top 7 Lessons Learned from COVID-19 Pandemic}

\author{
Priyanka Jayakumar \\ School of Computer Science and Engineering \\ Taylor's University \\ Selangor, Malaysia \\ priyankas.jayakumar@sd.taylors.edu.my
}

\author{
Sarfraz Nawaz Brohi \\ School of Computer Science and Engineering \\ Taylor's University \\ Selangor, Malaysia \\ sarfraznawaz.brohi@taylors.edu.my
}

\author{
Noor Zaman \\ School of Computer Science and Engineering \\ Taylor's University \\ Selangor, Malaysia \\ noorzaman.jhanjhi@taylors.edu.my
}

\begin{abstract}
No one predicted the coronavirus outbreak, and naturally, nobody was prepared. The coronavirus, otherwise, adoringly known as COVID-19, has put the entire world in a difficult position because of the apparent life-threatening danger it poses and the rate of spread and infection worldwide. Besides taking away so many lives, it has caused a variety of problems such as unemployment, social distancing, disruption of businesses and daily life. Circumstances are worse for those who live from hand to mouth. Within the three months of its presence, COVID-19 has forced humanity to find and implement alternative ways to sustain businesses and life. In this research paper, we have unearthed 7 lessons learned from the COVID-19 pandemic. These lessons include aspects of business, education, online presence, network communication, cybersecurity, healthcare, and the purpose of life. This research delves deeper into the response to the unannounced pandemic in hand. It aims to provide the right direction to address a potential pandemic in the future should it happen.
\end{abstract}

Keywords- COVID-19, Pandemic, Healthcare, Online Education, Online Business, Internet, Cyber Security

\section{INTRODUCTION}

According to the World Health Organization (WHO), the coronavirus was identified on the 31st December 2019 in Wuhan, China and the first case outside of China was reported on the 13th January 2020 in Thailand. After much research, forums, expert discussions and interviews, and studies, the disastrous virus outbreak was characterized as a pandemic on the 11th March 2020 [1]. Seeing how the rate of infection of COVID-19 was insanely high, medical authorities advised the public to stay indoors to avoid any form of social contact and those who were exposed to the infection or visited infected places/countries were isolated for 14 days and treated if they showed symptoms of the virus.

While there are many unsupported speculations and theories on how the virus escaped from a lab in Wuhan where it was allegedly created via genetic engineering, microbiology researchers and experts are convinced that the virus emerged naturally and evolved to be deadlier through natural selection [2]. Typical symptoms include cough, fever, and fatigue, while some people may also have diarrhoea or headaches. What's worse about this virus is that an infected person can be asymptomatic [3 - 4]. This airborne virus is transmitted via respiratory droplets from symptomatic people and contaminated objects and surfaces.
As of the beginning of May 2020, there are over 3 million confirmed cases and over 200,000 deaths caused by the coronavirus. Overall, the total number of confirmed cases and deaths are increasing every day. More than 200 countries are hit by the virus with the United States of America, leading the list with the highest number of confirmed cases [5]. The rapid spread of the coronavirus in economically advanced countries in the world shows just how unprepared we are in the face of a pandemic like this that demands a swift medical response, law enforcement, economic continuity to sustain the livelihoods of humanity.

Although there is rapid research emerging in the areas of technologies such as Artificial Intelligence, 3D Printing Technology, Big Data Analytics, High Performance Computing and Telecommunication Technology to combat COVID-19 [6], at present, businesses and people worldwide are struggling to survive these unprecedented times [7]. The daily routine has been disrupted and life as we know it has changed for the foreseeable future. All aspects of life such as economy, social, politics, law, culture, and many more, have been impacted one way or another, with the biggest problem of all being unemployment. Many people are getting laid off as businesses cannot afford to pay employees since there is no revenue. For instance, the manufacturing sector has ceased operations because not only is there a lack of orders and strict socialdistancing law in place but retaining employees when existing stock is proving difficult to be released has become a dealbreaker.

\section{LESSONS LEARNED FROM COVID-19}

Various studies and media have done an exceptional job by covering all aspects of COVID-19 as it progressed day by day. This includes daily updates from all sectors that are affected by the pandemic and how they are overcoming the obstacles. Absorbing all this information, we realized there were a few lessons presented by the global crisis from which humanity can benefit from if the world faces another disaster like this in the future. These lessons touch elements of business, education, online presence, network communication, cybersecurity, healthcare, and the purpose of life. The lessons mentioned above are illustrated in Figure 1, explained in the forthcoming sub-sections. 


\begin{tabular}{|c|c|c|c|c|c|c|}
\hline 臣 & 果 & a & " & $((t p p))$ & & 8 \\
\hline $\begin{array}{l}\text { Healthcare } \\
\text { Sector }\end{array}$ & $\begin{array}{l}\text { Working From } \\
\text { Home (WFH) } \\
\text { policy }\end{array}$ & Online Education & $\begin{array}{l}\text { Growth of Online } \\
\text { Business }\end{array}$ & $\begin{array}{l}\text { Need for Good } \\
\text { Network } \\
\text { Connection }\end{array}$ & $\begin{array}{l}\text { Cybersecurity is a } \\
\text { Priority }\end{array}$ & $\begin{array}{l}\text { Reconnecting } \\
\text { with Oneself and } \\
\text { Loved Ones }\end{array}$ \\
\hline \multirow{3}{*}{$\begin{array}{l}\text { Need of centralized } \\
\text { patient records } \\
\text { Digitalizing } \\
\text { processes, } \\
\text { operations, and } \\
\text { records }\end{array}$} & $\begin{array}{l}\text { Increased } \\
\text { productivity }\end{array}$ & $\begin{array}{l}\text { Virtual teaching and } \\
\text { learning }\end{array}$ & \multirow{5}{*}{$\begin{array}{l}\text { Delivery business } \\
\text { Job opportunities } \\
\text { Source of income } \\
\text { during an economic } \\
\text { downtum }\end{array}$} & $\begin{array}{l}\text { Internet has become } \\
\text { a basic need }\end{array}$ & $\begin{array}{l}\text { Rising coronavirus- } \\
\text { themed cyberattacks }\end{array}$ & \multirow{5}{*}{$\begin{array}{l}\text { Learning to detach } \\
\text { from the world and } \\
\text { focus on oneself } \\
\text { Appreciate and } \\
\text { bond with famuly } \\
\text { members } \\
\text { Take time to find the } \\
\text { purpose in life }\end{array}$} \\
\hline & $\begin{array}{l}\text { Converuence and } \\
\text { comfort }\end{array}$ & $\begin{array}{l}\text { Emergence of online } \\
\text { meeting and } \\
\text { learring platforms }\end{array}$ & & $\begin{array}{l}\text { Serves various } \\
\text { purposes during a } \\
\text { global emergency }\end{array}$ & $\begin{array}{l}\text { Online } \\
\text { meeting/collaborati } \\
\text { on platforms and the }\end{array}$ & \\
\hline & Internet & $\begin{array}{l}\text { Introduction of } \\
\text { online assessments }\end{array}$ & & & $\begin{array}{l}\text { healthcare sector is a } \\
\text { target }\end{array}$ & \\
\hline \multirow{2}{*}{$\begin{array}{l}\text { Upgrading of digital } \\
\text { infrastructure in } \\
\text { medical institutions } \\
\text { e-pharmacy \& e- } \\
\text { doctor } \\
\text { Appreciate medical } \\
\text { staff better }\end{array}$} & & $\begin{array}{l}\text { Review of grading } \\
\text { methods }\end{array}$ & & & \multirow[t]{2}{*}{$\begin{array}{l}\text { Poorly secured user } \\
\text { device and lack of } \\
\text { cyber safety } \\
\text { awareness among } \\
\text { people }\end{array}$} & \\
\hline & & & & & & \\
\hline
\end{tabular}

Figure 1: Top 7 Lessons Learned from COVID-19

\section{A. Transformation of the Healthcare Sector}

COVID-19 has made us understand the value of good health and the significance of the healthcare sector. While the whole world is advised to stay at home, medical staff work day and night to treat those who are infected by the deadly virus. At a time like this, the need for centralized patient records is felt as medical staff treating COVID-19 patients find it difficult to track some of the patients, especially when they are transferred from one medical institution to another for better observation and care [8]. For this to materialize, the healthcare sector must start digitalizing all their processes and records so that treatment is efficient and medical staff does not have to be burdened by tracking medical paper records. In addition to that, upgrading digital infrastructure in medical institutions would become essential once the healthcare sector goes digital. However, proper security technologies, controls and administration should be put in place to ensure a secure and robust environment for their operations and processes. Besides that, the COVID-19 pandemic has contributed to the emergence and growth of edoctor and e-pharmacy services that enable people to consult a doctor or pharmacist, get a prescription, get medical products or simply get health advice - all from the comfort of their homes via smart gadgets [9]. Focusing on health personnel who are risking their lives to save lives, these heroes must be treated better in terms of pay and other benefits to somewhat compensate for the sacrifice they are making for us all.

\section{B. Working from Home is Highly Possible}

Shortly after the peril of COVID-19 was unleashed, governments worldwide enforced the Movement Control Order that forced people to stay in their houses. This in return, birthed the Work From Home (WFH) policy where employees resumed work from the comfort of their homes. While some might argue that working from home is not the best of ideas, a study proves that employees who work from home are not only more productive, which results in getting extra work done, but they also find it easier to balance the work-life equation [10 - 11]. It is possible for an employee to spend more time on assigned tasks because they have extra time on their hands from the lack of commuting from their workplaces. Employees can also plan their day well so that they won't have to sit in a place to work at a time but have the option of spreading it out throughout the day, given that a task is not time-sensitive. This new way of life is so convenient where the only requirement for an employee to work is the Internet. Furthermore, the WFH policy has made employees more creative with work hurdles since they do not have all the resources they are probably used to at work. For example, where a brainstorming session or a meeting would happen with colleagues in the office, now the same thing is taking place virtually - for so much lesser time and effort.

\section{Online Education}

The crisis at hand has severely disrupted conventional teaching and learning and affected students' social life since all learning institutions have been ordered to shut down to avoid the spread of the virus. Students, especially children who have just started schooling, have temporarily lost the opportunity to increase social skills and social awareness for an unknown period [12]. To carry on with the teaching and learning process, institutions have instructed academicians to conduct classes virtually using online tools/services that may or may not have been tested before. Academicians find themselves in a different teaching environment where all their students are present within a computer screen as they deliver study content via online meetings and learning platforms. Besides that, all kinds of traditional and typical assessments (tests, quizzes, practical labs, viva, exams) are no longer possible. To overcome this issue, these assessments have been replaced with online assessments to measure student performance for the time being [13 - 14]. Not only that, grading methods, assessment rules and regulations, and overall syllabus structure are also being reviewed to ensure students are evaluated fairly given all the shortcomings. 


\section{Growth of Online Businesses}

As the lockdown kicked in, businesses of all sectors took a bad hit. However, some of them managed to turn their business online, and for others, business flourished due to the lockdown. A very good example is any kind of delivery business and online shopping. The concept here is simple: since customers are not allowed to any business premises unless completely necessary, necessities are brought to customers' doorstep. The business was booming for those who took it online [15 - 16]. Moreover, the drastic growth of online businesses is also opening job opportunities for many. A few weeks ago, Amazon hired 175, 000 additional workers who are working at sites across the U.S. [17] Online business has also proved to be a great source of income for ordinary people, specifically for those who live from hand to mouth. For example, in Malaysia, several homemade food and festive cookies online delivery businesses emerged, especially during the fasting month. People are getting creative with business offerings - from all kinds of food delicacies to hand-made accessories to selling home-grown fruits and vegetables - to earn extra on the side while abiding by the law.

\section{E. Need for Good Network Communication}

Looking closely at the lessons learned documented so far, one thing all of them have in common is Internet connectivity. The COVID-19 pandemic has proven that the Internet has become a basic need to stay informed and survive a global emergency like the one that is happening right now. Even before the pandemic, the whole world was already moving into the digital world because of the endless opportunities and possibilities that come with the virtual realm. During a crisis like this, it's important to stay up-to-date with new findings/status of the disease, reach out for online medical consultation if necessary, working from home to sustain a livelihood, and staying in touch with loved ones who are far away, and also for entertainment purposes [18]. There's no more denying that everyone needs to own a smartphone at least and have access to a good network connection, especially in rural areas where Internet connectivity is usually poor, including first world countries like the United States of America [19]. Now, it is vital more than ever to make sure everyone is accessible to the Internet with a good connection to stay connected and look out for one another.

\section{F. Cybersecurity is a Priority}

Since the whole world is pretty much spending all their time online, it's the perfect time for malicious attackers to up their game to hit the jackpot. Currently, coronavirus-themed cyberattacks are a huge hit, with phishing scams leading the troop [20 - 22]. Hackers are getting more and more intelligent in bypassing security technologies and controls to exploit anything they can get their hands on. In worse case scenarios, heartless, ethicless hackers target the healthcare sector to exploit medical resources and deny access to critical care systems that can cause deaths [23 - 24]. Another famous target that has become the centre of attention for hackers during COVID-19 is online meeting and collaboration platforms. Since everyone is working from home, meetings are conducted online, and utilizing some of the popular online services/tools narrows down the scope for hackers. Other than that, insecurely configured VPN and remote access tools are open-invitations for hackers to take control over business IT infrastructure since just about all the popular technologies out there today ooze unpatched vulnerabilities with a temporary, vulnerable workaround attached to them [25]. Talking about reasons behind a user morphing into a cyberattack victim, poorly secured user devices, and the user's lack of cyber awareness are among the top reasons for an attacker's successful exploitation. The fact is, cybersecurity will remain crucial as long as the Internet exists. So, it's time to give it some serious thought to go over existing security technologies in organizations and educate people on cybersafety.

\section{G. Reconnecting with Oneself and Loved Ones}

Most people think it is unacceptable to stay at home, not socialize with others, or in other words, detach from the world. Social media is overflowing with people ranting their unhappiness and loneliness during the lockdown period. However, if only one looked a little deeper into reality, they would realize that the life-threatening global crisis has brought us all one step closer to finding ourselves and presented the opportunity to understand loved ones better. Those who live with family during COVID-19 will inevitably start to form a stronger bond among themselves since they live in the same space, and for those who are far away from family, the importance of family will be instilled and they will learn to appreciate family more [26 - 27]. Regardless of lockdown with family, each one of us has finally gotten the time to reconnect with ourselves: be it focusing on health, mental and emotional stability, picking up a new hobby, writing a diary, finishing a book or even making long-term life plans. All of us have the time now to shift the focus, look deeper, reflect on ourselves, and become a better person than we were yesterday. In short, all of us should become optimistic people who look at the bright side of life and realize the opportunity to be happy in the grief and disruption COVID-19 has brought the world.

\section{CONCLUSION AND Future WORK}

Many issues are surfacing quickly as we lead our lives parallel to the worsening pandemic at hand. So far, some of the issues have been tackled prematurely due to a lack of clear, immediate back-up plans. In contrast, other issues are being managed as best as possible, but without a clue as to how to solve them, so everyone involved survives without severe consequences. The lessons discussed above are only some of the many critical lessons COVID-19 has taught us all. There may be more to come so be prepared in worse case scenarios, staying vigilant with the happenings in the world, and planning ahead in the event of a disaster will prove to be a good approach when faced with a pandemic like COVID-19.

Moving forward, governments and authorities should focus more on transforming the healthcare sector while giving cybersecurity the utmost priority. This is because all sectors are leaning towards going online as much as possible to ensure business continuity. Furthermore, research on medical systems and technologies that can cater to virus containment and eradication should be in process to get rid of a problem when it 
is still in its early stage. To avoid people dying of hunger rather than the pandemic itself, governments should allocate a certain percentage of their yearly budget to make funds for those in need, so they don't lose their livelihood and financial aids for businesses to survive when faced with an economic downturn.

\section{REFERENCES}

[1] "WHO Timeline - COVID-19", Who.int, 2020. [Online]. Available: https://www.who.int/news-room/detail/27-04-2020-who-timeline--covid-19. [Accessed: 07- May- 2020]

[2] P. Beaumont, "Where did Covid-19 come from? What we know about its origins", the Guardian, 2020. [Online]. Available: https://www.theguardian.com/world/2020/may/01/could-covid-19-bemanmade-what-we-know-about-origins-trump-chinese-lab-coronavirus. [Accessed: 07- May- 2020]

[3] Z. Zu, M. Jiang, P. Xu, W. Chen, Q. Ni, G. Lu and L. Zhang, "Coronavirus Disease 2019 (COVID-19): A Perspective from China", Radiology, p. 200490, 2020 [Online]. Available: https://pubs.rsna.org/doi/full/10.1148/radiol.2020200490. [Accessed: 07May- 2020]

[4] "Coronavirus: All you need to know about symptoms and risks", Aljazeera.com, 2020. [Online]. Available: https://www.aljazeera.com/news/2020/01/coronavirus-symptomsvaccines-risks-

200122194509687.html?utm_source=website\&utm_medium=article_pa ge\&utm_campaign=read_more_links. [Accessed: 07- May- 2020]

[5] "Coronavirus Update (Live): 3,822,989 Cases and 265,084 Deaths from COVID-19 Virus Pandemic - Worldometer", Worldometers.info, 2020. [Online]. Available: https://www.worldometers.info/coronavirus/?utm_campaign=homeAdve gas1?. [Accessed: 07- May- 2020]

[6] Brohi, Sarfraz Nawaz; Jhanjhi, NZ; Brohi, Nida Nawaz; Brohi, Muhammad Nawaz (2020): Key Applications of State-of-the-Art Technologies to Mitigate and Eliminate COVID-19. TechRxiv.Preprint. https://doi.org/10.36227/techrxiv.12115596.v2.

[7] "Addressing the economic challenges of COVID-19 in developing countries - IGC", IGC, 2020. [Online]. Available: https://www.theigc.org/covid-19/. [Accessed: 07- May- 2020]

[8] "Coronavirus COVID-19 brings challenges to developed healthcare systems | MSF", Médecins Sans Frontières (MSF) International, 2020. [Online]. Available: https://www.msf.org/new-approach-public-healthbig-change-needed-fight-covid-19. [Accessed: 07- May- 2020]

[9] C. Alessi, "The effect of the COVID-19 epidemic on health and care - is this a portent of the 'new normal'?", Healthcare IT News, 2020. [Online]. Available: https://www.healthcareitnews.com/blog/europe/effect-covid19-epidemic-health-and-care-portent-new-normal. [Accessed: 07- May2020]

[10] "The Benefits of Working From Home", Airtasker Blog, 2020. [Online]. Available: https://www.airtasker.com/blog/the-benefits-of-workingfrom-home/. [Accessed: 07- May- 2020]

[11] "Productivity and Effectiveness of Working from Home", SUNY Digital Repository, 2020. [Online]. Available: https://dspace.sunyconnect.suny.edu/handle/1951/71150. [Accessed: 07May-2020]

[12] J. Saavedra, "Educational challenges and opportunities of the Coronavirus (COVID-19) pandemic", World Bank Blogs, 2020. [Online]. Available: https://blogs.worldbank.org/education/educational-challenges-andopportunities-covid-19-pandemic. [Accessed: 07- May- 2020]

[13] S. Burgess and H. Sievertsen, "The impact of COVID-19 on education | VOX, CEPR Policy Portal", Voxeu.org, 2020. [Online]. Available: https://voxeu.org/article/impact-covid-19-education. [Accessed: 07May- 2020]

[14] "COVID-19 Educational Disruption and Response", UNESCO, 2020. [Online]. Available: https://en.unesco.org/covid19/educationresponse. [Accessed: 07- May- 2020]
[15] S. Meyer, "Understanding the COVID-19 Effect on Online Shopping Behavior", The BigCommerce Blog, 2020. [Online]. Available: https://www.bigcommerce.com/blog/covid-19-ecommerce/\#covid-19mens-and-womens-shopping-behaviors-vary. [Accessed: 07- May- 2020]

[16] C. Ungerer and A. Portugal, "Leveraging e-commerce in the fight against COVID-19", Brookings, 2020. [Online]. Available: https://www.brookings.edu/blog/future-

development/2020/04/27/leveraging-e-commerce-in-the-fight-againstcovid-19/. [Accessed: 07- May- 2020]

[17] D. O. Staff, "Amazon has hired 175,000 additional people," US Day One Blog, 01-May-2020. [Online]. Available: https://blog.aboutamazon.com/company-news/amazon-hiring-foradditional-75-000-jobs. [Accessed: 07-May-2020].

[18] "Networking in the Age of COVID-19", Kornferry.com, 2020. [Online]. Available: https://www.kornferry.com/insights/articles/job-networkingsearch-coronavirus. [Accessed: 07- May- 2020]

[19] P. Nichols, T. Kohn, N. Haney, S. Boorjian, M. Gettman, H. Patel, C. Stimson, P. Pierorazio and M. Johnson, "Access to Urological Care and Internet Connectivity in the United States: A Geospatial Analysis", Urology Practice, vol. 6, no. 5, pp. 275-281, 2019 [Online]. Available: https://www.auajournals.org/doi/abs/10.1097/UPJ.0000000000000018. [Accessed: 07- May- 2020]

[20] A. Tabrez, "Corona Virus (COVID-19) Pandemic and Work from Home: Challenges of Cybercrimes and Cybersecurity", SSRN, 2020 [Online]. Available: https://ssrn.com/abstract $=3568830$ [Accessed: 07- May2020]

[21] D. Grober, "Roundup: COVID-19 pandemic delivers extraordinary array of cybersecurity challenges |ZDNet", ZDNet, 2020. [Online]. Available: https://www.zdnet.com/article/roundup-the-coronavirus-pandemicdelivers-an-array-of-cyber-security-challenges/. [Accessed: 07- May2020]

[22] T. Aladenusi, "COVID-19's Impact on Cybersecurity", Deloitte Nigeria, $2020 . \quad$ [Online]. Available: https://www2.deloitte.com/ng/en/pages/risk/articles/covid-19-impactcybersecurity.html. [Accessed: 07- May- 2020]

[23] D. Winder, "Cyber Attacks Against Hospitals Have 'Significantly Increased' As Hackers Seek To Maximize Profits", Forbes, 2020. [Online]. Available: https://www.forbes.com/sites/daveywinder/2020/04/08/cyber-attacksagainst-hospitals-fighting-covid-19-confirmed-interpol-issues-purplealert/\#3db65c1f58bc. [Accessed: 07- May- 2020]

[24] N. Eddy, "Cyberattacks continue to mount during COVID-19 pandemic", Healthcare IT News, 2020. [Online]. Available: https://www.healthcareitnews.com/news/cyberattacks-continue-mountduring-covid-19-pandemic. [Accessed: 07- May- 2020]

[25] P. Jayakumar, "VPN and remote access tools widen the enterprise attack surface", secblog.kaapagamtech.com, 2020. [Online]. Available: http://secblog.kaapagamtech.com/post/2020/04/30/vpn-and-remoteaccess-tools-widen-the-enterprise-attack-surface. [Accessed: 07- May2020]

[26] H.R. Marston, C. Musselwhite, R.A. Hadley, "COVID-19 vs Social Isolation: the Impact Technology can have on Communities, Social Connections and Citizens", The British Society of Gerontology, 2020 [Online].

Available: https://ageingissues.wordpress.com/2020/03/18/covid-19-vs-socialisolation-the-impact-technology-can-have-on-communities-socialconnections-and-citizens/ [Accessed: 07- May- 2020]

[27] "Reconnecting with Family Members During a Pandemic - Self-isolating Novel Coronavirus Disease Outbreak COVID-19", LOCALTACTIC, 2020. [Online]. Available: https://localtactic.co.nz/reconnecting-withfamily-members-during-a-pandemic-coronavirus-disease-covid-19/. [Accessed: 07- May- 2020] 